\title{
Nationalism, Patriotism and Political Ideas of Sir Syed Ahmad Khan: an Analysis
}

\author{
Tanjeel Ahmed \\ Aligarh Muslim University, India \\ International Islamic University Malaysia, Malaysia \\ Email: tanjeelahmad88@gmail.com \\ Muhammad Amin \\ International Islamic University Malaysia, Malaysia \\ Email: mohd_amin_mt@yahoo.com
}

\begin{abstract}
Sir Syed Ahmad Khan (Founder of Aligarh Muslim University) was born into a noble Muslim family in 1817; he was a distinguished scholar while working as a lawyer at the British East India Company. After realizing the worthless condition of Muslims, his approach to western education for the benefit of the Muslim community became a priority. This study contemplates that Sir Syed was religiously oriented and very politically aware of nationalism and patriotism. The author uses primary data and also secondary data. The author also explores his main books and articles; the author aims to examine Sir Syed's nationalist and political ideas concerning political significance for Muslims in India. The writer would like to know the result that, what is the reason, Sir Syed was against the Indian National Congress. At the same time, the whole Indian society was afraid of the British, but Sir Syed maintained his good relations with the British, and he also showed the loyalty of the Muslims towards them. This study found the conclusion about Sir Syed that he became a symbol of communal harmony.
\end{abstract}

Keywords: Sir Syed, Nationalism, Political Ideas, Community Harmony.

\begin{abstract}
Abstrak
Sir Syed Ahmad Khan (Pendiri Universitas Muslim Aligarh) lahir di keluarga Muslim yang mulia tahun 1817; dia adalah seorang sarjana terkemuka saat bekerja sebagai ahli hukum di British East India Company. Setelah menyadari kondisi umat Islam yang tidak berharga, pendekatannya terhadap pendidikan barat untuk kepentingan komunitas
\end{abstract}


Tanjeel Ahmed, Muhammad Amin

Muslim menjadi prioritas. Studi ini merenungkan bahwa Sir Syed tidak hanya berorientasi pada agama, tetapi sangat sadar akan politik tentang nasionalisme dan patriotisme. Penulis menggunakan data primer dan juga data sekunder. Penulis juga menelusuri buku-buku dan artikel-artikel utamanya, penulis memiliki tujuan untuk mengkaji gagasan nasionalis dan politik Sir Syed dalam kaitannya dengan signifikansi politik bagi umat Islam di India. Penulis ingin mengetahui hasil bahwa, apa alasannya, Sir Syed menentang Kongres Nasional India, sementara seluruh masyarakat India takut pada Inggris, tetapi Sir Syed mempertahankan hubungan baiknya dengan Inggris, dan dia juga menunjukkan kesetiaan umat Islam terhadap mereka. Kajian ini menemukan kesimpulan tentang Sir Syed bahwa ia menjadi lambang kerukunan komunal.

Kata kunci: Sir Syed, Nasionalisme, Ide Politik, Kerukunan Masyarakat.

\section{Introduction}

Sir Syed was a great nationalist of the British and Hindu-Muslim unity; initially, he was a proponent of the unity of British India. The first era of the 19thcentury was the time for the downfall of the great Mughal Empire. Sir Syed belonged to a very reputed family, his paternal grandfather was a 'Hazari', and they were all government servants during the Mughal reign. Sir Syed was born on October 17, $1817 \mathrm{CE}$, in the dark age of the Indian Msuslims. Sir Syed realized the tragic conditions of the Indian Muslims in every sphere of life: educational, social, religious, and political (Iqbal, 1989). It was the time when the Mughal Empire started its downfall in India, during the period he received his early education from the Madrasa. He was a very excellent learner of Urdu, Persian, English, and Arabic. He was not merely a great personality but also a significant movement in himself.

He was appointed as a Qazi (Judge) in the British government. He worked as a government official with the Britishers. He tried to comprehend the policy of the British Government about how these few people subjugated most of the land of the Indian subcontinent. Sir Syed appreciated the administration and educational system of the British. When Sir Syed faced challenges and witnessed the miserable conditions of the Indian Muslims, he understood that education is the only mode to answer all the questions. Education was the prime issue of Indian Muslims, and it was merely a policy adopted by Sir Syed to uplift Indian Muslims. The whole country was affected by the revolutionary freedom movement of India. Muslims and other 
Nationalism, Patriotism And Political Ideas of Sir Syed Ahmad Khan: an Analysis

communities of India participated in the freedom movement. But to lead the issue of education, the British Government had established the school. The Muslim Ulema refused to receive an English education, but Sir Syed was the 'Man of Vision' of future time. Only a Modern Madrasa could uplift the Muslim Society. So, he considered establishing the Modern Madrasa for the Muslim community. Through door to door, he collected the donations and established a Modern Madrasa in 1875 named 'Muhammadan Anglo-Oriental College'; after that, it changed into the University in 1920.

Sir Syed wrote copious books, but after Bijnour's rebellions, he was shocked; then Sir Syed produced two Monumental works, Asbab-eBaghwat-e-Hind (1858) and 'Khutubat-e-Ahmadiyya (1870).' From the writings of Asbab-e-Baghwat-e- Hind, Sir Syed tried to expose the causes of the Indian mutiny by laying the blame on Muslims. It may be considered the most reliable book of the history of that region. Politics was not an interesting part of Sir Syed, and he never actively indulged in politics, but he was fully aware that the formation of the national government is feasible. The formation of the government would be on the basis o Majority and minority. And the Muslims are in the minority, so; the Muslims should be focused on the development of modern science and philosophy.

The problem needs to understand; Sir Syed was rejected by the Ulama of the Muslim community. The reason for the rejection of sir Syed Ahamd Khan's attitude and his proposal for modern education for Muslims was his rational approach to Islam. He wrote a Commentary on the Qur'an (Tafsir-ul-Qur'an), the Tafsir was based on the rational and scientific. So, it was the most controversial Tafsir. His other writings also have controversy like, Qur'an is the accurate Word of God but no Hadith, rejected the Miracle of Prophets, rejection of Pre-destination, no existence of Angels, no existence of magic, Concept of Heaven- Hell, etc. there were so many writings that depicts his rational approach about God and his creatures. Several periodicals such as Noor-ul-Afaq, Noor-ul-Anwar, and Taed-ul-Islam were started by his opponents in opposition to Tehzeeb-ul-Akhlaq to discourage Muslims from joining the Aligarh Movement of Sir Syed Ahmad Khan. These approaches were not acceptable by the traditional Ulama of that time, so, he has been declared as Kafir (Unbeliever) by the Traditional Ulama.

At the end of the 19th century, the Muslims were living in underprivileged miserable conditions. They were socially, 
economically, and even politically backward. They deliberately want to keep themselves away from modern education. But there were few Muslims who were receiving the traditional knowledge of Islam. He did not merely advise Muslims not to participate in politics but also advised them not to blindly follow their religion. He wanted to say that Islam never be traditional it needs reformation (Islah) reinterpretation (Ijtihad) according to time. He was the "man of vision' and profound intellectual. His vision was not simple to understand before the time, this plan was not for a decade or century, but he was looking for the future of upcoming generations in the Muslim community.

The present study would adopt both Primary and Secondary sources of information would be consulting for the in-depth analysis of the research. Subsequently, the collected material is analyzed and examined systematically and scientifically in a coherent manner with a sense of objectivity. Besides the above, the other sources that may impinge on the present study would also be given due attention to study. The study is also based on historical facts, so secondary and primary sources are relevant to make the study more reliable.

\section{Results and Discussion}

More than thousands of articles and books have been written on Sir Syed Ahmad Khan. Most of the articles were written on his life and his great work in the form of Aligarh Muslim University and even his upliftment of the Muslim community. The books were written on his particular thought like religious views and historical aspects. But very rare writings have been written on his nationalism and patriotism ideas, so the researcher tries to ponder the national, political, and patriotism ideas of Sir Syed Ahmad.

Before examining the views of Sir Syed on Nationalism, there is a need to study the Word "Qawm." Sir Syed indicates the meaning of this word as creed, caste, class, and as a social group. He describes Qadis, Mufti, Nawab, sheikh, and Sayyad as a Qawm (Panipati, 1990). He referred to the English, French, Germans, Greeks, Egyptians and Arabs as different Qawm. Before 1884, Sir Syed interpreted "Nation" as the word "National"; he said that "I include the Hindus and Muslims, which is the only meaning I can give." He articulates that the peoples of India are one 'nation', Hindus, Muslims, Bengali, Parsis all are as a 'Qawm,' and they all make a national identity, that is, 'Indians' (Jiang, 

of Sir Syed Ahmad Khan: an Analysis

2016). Sir Syed was aware of the pluralism of Indian society. India is a country that has massive diversities. The people of India are followers of different religions, but Sir Syed presents the idea of India as one Qawm. Indians and Britishers are different from Qawm because Britishers are not natives of India (Amir, 200o). The works of Sir Syed depict him as a lover of his community. In many speeches, he articulates to love our country by giving the reference to the Hadith of the Prophet Muhammad (PBUH). His efforts were focused on the education of the Muslim community, and he insisted that receiving the National education could be obtained in India only.

He started the Urdu Journal named 'Tehzeeb-ul-Akhlaq' in Aligarh, the purpose of publishing the 'Tehzib-ul-Akhlaq' was to promote faith and love for the motherland (Watan) and country (Balad). Sir Syed intended to say that Qawm in the term for both 'Watan' and 'Balad.' The motto of Tehzib-ul-Akhlaq was to transfer the sentiments of patriotism in order to create social reforms among the Muslims. He delivered a lecture in his college where he said that there would be no discrimination against any particular community; both Hindus and Muslims would be brothers and receive a similar education. All have equal rights to enjoy within the college, including the enlightenment of scholarship. He also thanked those Hindus who donated the spirit for the college (Amir, 2000). It depicts that Sir Syed wanted to make one nation comprising of Hindus and Muslims.

In India, Sir Syed, in his speech (February 3, 1884), articulates that "by the word Qawm, I mean Hindus and Muslims both. This is the sense in which I interpret the word 'nation'. He was unhappy to realize that only Hindus consider themselves Indians and Muslims are foreigners (Amir, 200o). Not only Hindus but also Muslims are the natives of Hindustan. The Aryans came to India for prolonged periods. The people of India mixed up with Aryans, and they all called themselves "Hindu" (natives of India). Even the Hindu Aryans are not natives of Hindustan, and there are many Muslims found in India whose blood match with the Aryans. Both the communities of Hindus and Muslims have been living in India for long periods. He added that "India is like a bride who has two beautiful eyes; if one eye is lost, it would lose its beauty" (Panipati M. I., 1963). Sir Syed said that not only Hindus and Muslims are two communities are in India, but also the followers of other religions are also the natives of India. It is the depiction of a great lover of the geographical nationalism of Sir Syed (Panipati M. I., 1979). 
His speculation was on the conflict among all the communities of India that make our country very weak, disappointed and it would be shattered into pieces. The blessing of living together has departed from us. It brings to standstill progress for the country. So, there is a need to change this discord and enmity with unity and solidarity through mutual love (Khan, 2004). Sir Syed said: "at present, the great cause of our decline as a people is that we have forgotten the idea of National Unity." Sir Syed was partly impressed by Tipu Sultan (Ruler of Mysore, Known as 'Tiger of Mysore') because of his secular and nationalist outlook (Khan, Muslims In India, 2004). According to Sir Syed, politics is not a solution to every problem related to the Nation, and but merely education is the safeguard of our culture, tradition, and religious identity. He said that some people hold an option that our national cause will be promoted in the best way by discussing political discourse. But I do not agree with them because the spread of education is the only means to the promotion of our national cause' (Raza, 2001). Sir Syed played a significant role in giving the solution of the national cause and national development in such a critical time. Jawaharlal Nehru (First Prime Minister of India) wrote in his book Discovery of India, p.298: 'Sir Syed was in no way anti-Hindu or communally separatist. But he only opposed the formation of Congress in 1885'.

The family of Sir Syed had traditional relations with Hindus. When his maternal grandfather Nawab Fariduddin Khan divided his property to his son, he also gave an equal share to his Hindu diwan Lala Muluk Chand. He treated him as a family member. When Sir Syed established a madrasa in Ghazipur, and Raja Dev Narayan Singh was invited. When Sir Syed was in Delhi, he always participated in all the festivals of Hindus. When he was in his last days, there were 285 Muslim students, 64 Hindus students, and 7 Hindu teachers in the Muhammadan Anglo-Oriental College (MAO). An excellent example of Sir Syed of communal harmony was that he gave gold medals from his pocket to Hindu students who got the first division in bachelor's degree (Nizami, 1985).

Sir Syed promoted communal harmony by inter-faith dialogue. He wrote commentaries on the Bible to make good relations with the Christians, and he did a sympathetic study of the Bible to make social interaction with Christians (Ansari, 1989). He also advised destroying the British policy of divide and rule (AMU, 1998). In 1860, he started to release a pamphlet called the 'Loyal Muhammadans of India' in which 

of Sir Syed Ahmad Khan: an Analysis

he argumented that Jihad is not permissible in India, and he recorded the veracious account of Muslim nobleness (Jain, 1983).During nobleness, he was the symbol of communal harmony. That was the time when there were three communities in India British, Muslims, and Hindus; it was critical to think about how to face the challenges of communalism. Some people were supporting the British Government, and some were against it and were demanding their freedom. The great clash of the ideology of Sir Syed emerged then Sir Syed wrote many articles to bring Hindus and Muslims together on one platform. He described that he heard the people of Bareilly who had given the proof of love and majestic of communal harmony. One incident he has explained is the collection of funds collected by the Hindu and Muslim communities to construct a mosque in Dhaka (now in Bangladesh). Therefore, Sir Syed showed his sympathy and congratulated them on maintaining brotherhood (Khan, Selected Essay of Sir Syed Ahmad, 2004).

Sir Syed was the symbol of Hindu Muslim unity; he delivered a speech at Gurdaspur on January 27, 1884; he said: "O Hindu and Muslim! Do you belong to a country other than India? Don't you live on this soil; are you not buried under it or cremated on its ghats? If you live and die on this land, then bear in mind, that... all the Hindus, Muslims, and Christians who live in this country are one nation" (Sir Syed Ahmad Khan).

The Christians are also part of the Indian national, the word 'Qawm' does not merely related to Hindu Muslim unity, but every community which is living in India is related to 'Qawm'. Hindu are in the majority and Muslims are in the minority and others communities (Sikh, Christian, Parsi, Jain, and Buddhist) are also in minorities, and the Muslims are the second-largest majority in India, so under the British rule in India, both communities have conflicted to each other, that's why Sir Syed indicated to both (Hindu and Muslim) as a 'Qawm' because of continuous conflict between both.

Sir Syed had not discussed about any specific types of government in his writings but he described what he felt. He thought that God did not create any political society it's a management of the Human Beings according to their suitable match. Human society form with two things, government and its citizens, both have same collaboration to form the civilized society. Mercy must have the main role in making society better, the state must be the results of mercy but citizens also show mercy towards the state. The Sir Syed did not participate in 
politics, but he was much influenced by some events in England. The best example was 'the subjugation of the Britishers' on the most of the land of the world (Muhammad, 1969).

Sir Syed was not merely an educationist but also a political thinker of his time. His political ideas concerning his contemporary plights were penned down by him, giving an overview of what he felt about politics. He objectively analyzed the real cause of the revolt. Sir Syed was an eyewitness of the mutiny of 1857 . The mutiny of 1857 greatly impacted Sir Syed, and he worried about Indians because of the killings of both the communities, Hindus and Muslims. Sir Syed realized that Muslims could not defend their rights without gaining the knowledge of science and technology, without which all efforts of political emancipation would prove futile. He delivered a lecture in Amritsar (a place in India), where he said: "if the government has not conceded some of our rights to us as yet, for which we may have a grudge, higher education, is such a thing that it will secure those rights for us, maybe willy-nilly, or against its wishes." (Jain, 1983). Asbab-i-Baghwat-e-Hind (The Book of Sir Syed, The causes of Indian mutiny) was a significant work of Sir Syed Ahmad Khan, but the government ignored the conditions of its subject while the people were unable to understand the policy of British rule (Nizami, 1985). It was the first political pamphlet written by an Indian in the British Government. Even the founder of the Congress, A.O. Hume (Allan Octavian), himself said that he was much impressed by this booklet (AMU, The Glowing Legend of Sir Syed, 1998).

The political ideas of Sir Syed were influenced by the remarkable events which took place in England in the 19th century. It was the time of the rise of Britain's most enormous world power. And it made Sir Syed understand the whole politics of India. Sir Syed was also influenced by the political ideas of Lord Ripon and Gladstone (AMU, The Glowing Legend of Sir Syed, 1998). Monarchy, constitutional monarchy, parliamentary, and presidential government are forms of government. He did not like monarchy or even constitutional monarchy. He also opposed every type of hereditary rule. Sir Syed said: "I am Musalman (Muslim), an inhabitant of India, belong to the Arab race. From these two facts that I am a descendant of Arabs and Musalman, one can infer that I am a true radical from the religious and national point of view and then my religion is Islam and teaching radical principles and is not compatible with the despotic rule; neither is it like limited monarchy for it dislikes all hereditary Government." 
Nationalism, Patriotism And Political Ideas of Sir Syed Ahmad Khan: an Analysis

According to Sir Syed, any political agitation is harmful. Any agitation (Dharna-Pradarshan in Hindi) has no justification, and it does not matter which type of government is ruling. In the republic government, it demands to remove the president; in parliamentary government, it affects the ministers, and in a monarchy, it directly affects the ruler.

Sir Syed dared to convey his message through publishing to the government as well as the common people. Once, many people gathered around Sir Syed and were bickering. Even friends of Sir Syed said to him that the brochure would not be published. Another said to Sir Syed that you should burn it, but he ignored all the comments against his decision. But he printed a copy of the pamphlets and sent it to the Government of India (British Rule). There were men like Mr. Cecil Beadon (foreign Secretary) who considered the request of Sir Syed. It was the first time when the partial publication came in 1861, where Indians were admitted for the first time in the GovernorGeneral's legislative council (Sherwani, 1944).

Up to the end of the 19th century, there was no existence of a Muslim party in India. It did not mean that Muslims would segregate from the mainstream of politics. Not all Muslims were supporters of the Congress, but some Muslims were supporters of the education policy of Sir Syed. He realized the conditions of Muslims and asked them, based on non-religious dogmas, to refrain from active politics. He knew that Muslims were more backward and not able to get jobs in the British government. He insisted on uplifting the Muslims by education. 'Education is the only tool that would enable Muslims' upliftment in mainstream society. He never said that participation in politics is religiously forbidden. Sir Syed inculcated three ideas of politics. First, Muslims had to keep away from politics. Second, the British must be befriended. Third, Muslims should not join Congress (INC). He said that Muslims must leave politics until they have reached the level of Hindus. Aligarh (a place in India) became the symbol of Muslim politics, particularly when it became the Aligarh Muslim University. Sir Syed said that political rights: "were more important than religious traditions, and so long as the Muslims lived freely under British rule, they would remain good subjects." (Hasan, 1997).

The Hindus and Muslims were living under the British Government, and they had political differences. Most of the Hindus supported Congress because many prominent leaders were in 
Congress, but many Muslims were not supporting Congress and even against the policy of Congress also though Muslims and Hindus behave with love, friendship, solidarity, and respect for their religion.

As an educationist, Sir Syed opposed the Indian National Congress (INC). He was the contemporary of A.O. Hume, the British administrator, and also defended him on occasions, especially on the question of the foundation of a native volunteer's corps in India. Hume was the forerunner of the Indian National Congress. Still, he knew that Congress of those days was only a shock absorber about which A. O. Hume had himself said that it was 'a safety valve' for the escape of great and growing forces generated by our own action (AMU, The Glowing Legend of Sir Syed, 1998). The Muslims strongly rejected the Indian National Congress because the leaders of Congress were Hindu; the majority was Hindus and overwhelming the minority interest. The minority could not challenge the decision taken by the majority. And there would be no consideration for the minority. That is why Sir Syed feared that the Indian National Congress party's political interest would overwhelm the Indian Muslims (Lan Jiang, 2016).

Sir Syed was deeply disturbed to expect that a large number of young Muslims would gather for the forthcoming session, which was going to be organized in Madras; 'Badruddin Tayyabji' was the president of the session. In Lucknow's speech (1887), Sir Syed intentionally said that this speech was only for opposing the Congress. He also criticized the Badruddin Tayyabji for joining Congress and said that he made a mistake to take part in the National Congress. No Muhammadans from Madras and no 'Rais' from Bengal took part in the national Congress (Sir Sayyid Meerut). Badruddin Tayyabji wrote a letter to Sir Syed that if the Muslim delegates who would oppose Congress in any matter and the Congress would not take is it up. Sir Syed replied because Congress is a political body, there was no political question which would be opposed to the interest of the Muslims. Here, Dr. Rajendra Prasad (First President of India), seeing the whole scenario of opposing Congress by Sir Syed, said that 'Mr. Beck had utterly succeeded in misguiding and converting Sir Syed (Prasad, 2010). In 1888, Sir Syed established the 'United Indian Patriotic Association' (UIPA), which had a large number of Muslims, noble Hindus, and even English members. Through this association, he started to counter the activities of Congress (Amir S. , 2000). It depicts the primary leadership of Sir Syed. 

of Sir Syed Ahmad Khan: an Analysis

In the critic writings on Sir Syed Ahmad Khan, many times, it has been written that, Sir Syed merely care about the Indian Muslims and wanted to uplift them. The researcher has pondered that Sir Syed was not merely wanted to develop Muslims but also the other communities of India. After the downfall of the Mughal Empire in the mid of 19th century, India came under the rule of the British, so the conditions of Muslims became more deteriorate. It would be said that he was more focused the community, which was more in miserable plights and also facing the challenges of economic crises. He used the word 'Qawm', which indicates to all the community of India, whether they are Sikh, Muslims, Hindu, or others. It also depicts the unification of Indians and also one 'Nation'. So, all Hindus, Muslims, Sikhs have one National Identity that is 'Indian National'.

He wrote many articles and books on social upliftment. And he also started a journal named 'Tehzeeb-ul- Akhlaq'; the motive of this monthly journal was to send the ethical and social reformer message of Sir Syed to the Muslim community. Through these works, Sir Syed conveyed the messages of social developments and modern education to the Indians. Even Sir Syed used said, 'India is like a Bride'.

The researcher also finds in his study that Sir Syed was also the 'epitome of communal Harmony'. He had many friends who were Hindu; the researcher has mentioned the name of several Hindu friends. He also worked in collaboration with Hindus and set the highest tradition of goodwill, and also worked with the several communities of India.

Sir Syed advised to the Muslims not to participate in politics. Muslims' conditions did not favor; Sir Syed knew that if they joined the political parties, they were in the minority, so the Muslims came into the system not and should not be part of politics. If the Muslims would not know about their rights, then how would they defend themselves? So, Muslims should have knowledge of modern science and technology. And Sir Syed know better that the, Education is the tool which makes strong in the system as well as in the country.

In the early period of Sir Syed Ahmad Khan, he did not have an idea about politics; he was just as a Munsif (Judge), but in the later period, he started to understand politics. When he saw the mutiny of 1857, he tried to write about politics, but he was neither involved in politics nor did he want Muslims to participate in politics. He devoted most of the part of his life, and he was merely worried about the underprivileged community of the Muslims in India because they 
were socially, politically and, economically backward. He tried to explain the 'meaning of rebellion, fighting against the establishment government, helping those who are enemies of the established authority, and explaining the laws and forces. He has not merely tried to explain to the government but also the rebellions. So, after that, he wrote several pamphlets and, through his writings, maintained peace in the country.

On the other hand, Sir Syed was much aware that the political decline of Mughal was also the decline of Muslims in India. The political ideas of Sir Syed directly related to forms of government based on circumstances. The people of any country must be live with peace and harmony. Like, India has its composite culture and it has diversities in caste, culture, and religions also. Even Sir Syed also wanted the unity in Muslims should be through education. His prime motive was to empower the Muslims, whether in politics or in Modern education.

In the contemporary world, most minorities face the challenges of identity crises based on their nationality. As the minorities are compelled to show their love to the country, the word 'nationalism' is stereotyping, which depicts love for their own country. So, in all these plights, Sir Syed Ahmad Khan can icon for the young generations in the field of love, unity, education, and practitioner of religion. In the late 18th century, he was a mere person shows himself as a lover of their country and loyal to the British Mandate. In plights of British Mandate, nobody dares to write anything without the permission of the British Government; in such conditions, he wrote a book 'Asbab-eBaghawat-e-Hind' on the famous revolt of 1857 , which was famous mutiny in Indian history. His dynamic personality is not specific for Indians but for the whole world to learn the lesson.

\section{Conclusion}

Sir Syed was a 'man of vision'; he did not like to live in the past. Therefore, he wanted to create awareness among the Muslims on the realities of the world. He approached to the Britishers to make good relations between British and Muslims, to achieve all the goals. He proved himself as a great nationalist; Sir Syed was a great nationalistic in a political sense. He wanted the Muslims as an identity of Indian Muslim. And Hindus and Muslims should be one identity of Nation "Qawm". He was the symbol of communal harmony; he wrote many 
Nationalism, Patriotism And Political Ideas of Sir Syed Ahmad Khan: an Analysis

articles and delivered his speeches to maintain the brotherhood and unity of the nation. It was the period India was under the British mandate, and many Muslim intellectuals and elites were attached to the Congress, but they were not doing anything to uplift the Muslim community; even the conditions of Muslims were deteriorating. Sir Syed initiated the Muslim community educationally strong because education was the only weapon to make the Muslims uplifted and simultaneously the nation progress and develop further. Many Muslims clergies opposed him for providing English, modern and advanced education for Muslims.

\section{REFERENCES}

Amir, Safia. 200o. Muslim Nationhood in India. New Delhi: Kanishka Publisher.

AMU, Nigeria. 1998. The Glowing Legend of Sir Syed. Aligarh: Aligarh Muslim University.

Ansari, Iqbal. A. 1989. The Muslim Situation in India. New Delhi: Sterling Publisher private Limited.

Hasan, Muhammad. 1997. Legacy of a Divided Nation. Delhi: Oxford University Press.

Ansari, Iqbal. 1989. The Muslim Situation in India. Sterling Publisher Private Limited, 61.

Jain, N. K. 1983. Muslim in India: A biographical dictionary. Manohar Publication, II.

Jiang, D. Lan. 2016. The Evolution of Sir Syed Ahmad Khan's Political Identity. Cross-Cultural Communication, 6.

Khan, Sir Syed. 2004. Muslims In India. Aligarh: Aligarh Mulsim University.

Khan, Sir Syed. 2004. Selected Essay of Sir Syed Ahmad. Aligarh: Aligarh Muslim University.

Jiang, D. Lan. 2016. The Evolution of Sir Syed Ahmad Khan's Political Identity. Cross-Cultural Communication, 12, 7. 
Muhammad, Syed. 1969. Sir Syed Ahmad Khan A political biography. Meerut: Minakshi Prakashan.

Nizami, Khaliq Ahmad. 1985. Sir Syed Album. Delhi: Jayyed Press.

Panipati, Muhammad Ismail. 1963. Maqala-e- Sir Syed. Syed Imtiyaz Ali Taj, 41.

Panipati, Muhammad Ismail. 1979. Safaranama Punjab. Educational House, 200.

Panipati, Muhammad Ismail.-e.-S. 1990. Maqalat-e-Sir Syed. Majlise-Taraqqi Adab, V, 36.

Prasad, Rajendra. 2010. India Divided. New Delhi: Penguin Books.

Raza, Muhammad. 2001. Sir Syed A True Nationalist. Sir Syed Ahmad Khan; A centenary tribute.

Sherwani, Haroon Khan. 1944. The Political Thought Of Sir Syed Ahmad Khan. The Indian Journal of Political Science, 310.

Meerut, Sir Sayyid. n.d. Retrieved August 31, 2017, from http://www.columbia.edu/itc/mealac/pritchett/ooislamlinks/t xt_sir_sayyid_meerut_1888.html.

Khan, Sir Syed Ahmad.n.d. Retrieved October 17, 2017, from Aligarh Muslim University: https://indianexpress.com/ article/opinion/columns/misreading-sir-syed-ahmad-khan aligarh-muslim-university-489379. 